\title{
CONSERVATION-RESTORATION AND CONSERVATION SCIENCE - THE CHALLENGE OF TRANSDISCIPLINARITY
}

\section{NOLL-MINOR Mechthild ${ }^{1}$}

\begin{abstract}
1 Chief Conservator of the Department of Conservation-restoration and Building Research in the Brandenburg State Office for the Preservation of Historical Monuments, member of ICOMOS and of the NSC ConservationRestoration of Wall Paintings and Architectural Surfaces of ICOMOS Germany, member of the Board of the German Professional Association of Conservator-Restorers VDR Verband der Restauratoren https://orcid.org/0000-0002-8060-8467
\end{abstract}

ABSTRACT: Transdisciplinarity has shaped the development of both conservation science and conservation-restoration. The history of conservation science demands the commitment of all involved specialists to follow a common vision in the field. The present article highlights some key lessons to assist in closing the gap between the promotion of high-level research projects and the development and assessment of proficient professional practice in conservation science and conservation-restoration. The necessary framework conditions should also be brought to the attention of responsible politicians. Reflecting on conservation theory and practice "at the turn of the millennium" I propose to take a closer look at interdisciplinary work devoted to maintenance of Cultural Heritage since the beginning of the 20th century.

KEYWORDS: Transdisciplinarity, monitoring, quality assessment, mural painting, sepulchre

\section{Historic Development of the field and the involved disciplines}

Looking back into history we see the development of different disciplines, working for the maintenance of Cultural Heritage. The discipline of conservation-restoration in the modern sense - based on scientific analysis and aiming at minimal intervention and preventive conservation - would not have evolved without the development of investigation methods and their almost immediate application to the technical study of art (see also technical history of art) and cultural heritage.

The gradual integration of science into museums and conservation-restoration in general and the strengthening of the collaboration between conservator-restorers, conservation scientists, and curators constitute the early history of Conservation Science (Stoner and Rushfield, 2012). 
The first laboratories in Cultural Heritage institutions, i.e. at museums and high schools, were set up in the last decades of the 19th century.

In 1888 the Royal Museums of Berlin was the first to establish scientific facilities (Nadolny, 2012). Friedrich Rathgen became chemist in charge and acted not only on the Museums' artefacts: He began the first systematic research and monitoring project of the decay of stone and all kinds of buildings all over Germany that served for his investigations on the suitability of stone conservation materials. For this purpose, he placed over 1257 samples for direct and indirect weathering - 111 samples alone at the Cathedral of Cologne (Rathgen,1916). He compared treated (with different materials) and untreated stones, took photographic records and revisited them every three years. This early and outstanding monitoring project has had no successor at this large-scale in Germany until today.

An important aspect of Conservation science and Conservation is documentation. Visual examination and documentation were fundamental for the study and development of strategies to preserve works of art from the beginning. A pioneer of this activity in museums was George L. Stout (Stoner, 2015), who after studying and teaching arts at Iowa University studied art history at Havard University and worked as researcher at the art museum of Havard University - the Fogg Museum. In 1928 he was appointed chief of the new laboratory of the museum, and working closely with the chemist Rutherford J. Gettens became one of the first conservator-restorers in the modern sense. Together with Rutherford he pioneered systematic documentation, describing the examination of paintings and all interventions. Stout also motivated museum directors to enable "long-range conservation" by "a specific and exact and permanent record of the appearance of a painting" (Stout, 1949) and thus he prepared the ground for standardization of museum records.

Regarding his background it is not surprising that he described conservation-restoration as a critical act: "The job of restorer can in no way be regarded as the mere execution of instructions defined entirely outside of it by the critic or the laboratory ... The thought must always be there on alert, a thought that controls, interprets and adapts, i.e., continually creating because, like an aesthetic and technical problem, it resides within the work that it directs" (Stout, 1950). Stout coined the allegory of the "three-legged stool", highlighting the need for interdisciplinary collaboration among scientists, art historians, and conservators (Stoner, 2015).

The "International Conference for the Study of Scientific Methods for the Examination and Preservation of Works of Art", that took place in Rome in 1930, was organized by the International Museums Office (existing from 1926 till 1946, precursor of ICOM) under the umbrella of the International Institute of Intellectual Cooperation (existing from 1924 till 1946).

"Following this conference and beginning in 1933, twelve art historians, chemists, and conservators served as a 'committee of experts' to compile the Manual on the Conservation of Paintings (IOM, 1940). The manual, published in French in 1939 and English in 1940, listed the following 'special methods of examination applied to pictures': x-rays, ultra-violet rays, infra-red rays, microscopy and microchemical examination, refractive index determination, colorimetry to study 'pigments and colour mixtures', $x$-ray crystal structure analysis ('photographing the characteristic pattern of the rays resulting from diffraction by crystals in the paint film'-even without taking a sample, the manual suggests), and spectrographic examination of a sample of a few milligrams containing metallic constituents, to form a 'pattern of lines on a photographic plate'. The compilers noted that methods of 
absorption spectrography might be useful in the future to study binding media, organic pigments, and natural dyestuffs." (Stoner, 2015, §53).

In 1948 the Archives Centrales iconographiques d'Art national et Laboratoire central des musées de Belgique (renamed in 1957 Royal Institute of Cultural Heritage) were set up following the dictum of its first director Paul Coremans that the different disciplines of scientists, conservator-restorers, curators and art historians should work closely together (Stoner, 2015). He called that the "interpénétration des disciplines" - a quite appropriate expression anticipating the modern concept of Transdisciplinarity.

\section{The principle of Transdisciplinarity}

Under this term we understand a methodical approach to integrative research combining forms of scientific and practical knowledge. It requires adequate addressing of the complexity of problems and the diversity of perceptions of them, and requires the linking of abstract and case-specific knowledge (Mittelstrass, 2003).

Hence a transdisciplinary process in conservation science is not only an interaction of the involved disciplines but a new quality of integration of basic and applied knowledge and research. When the very nature of a research subject is under dispute, transdisciplinarity can help to determine the most relevant problems and questions involved.

Conservation science is a complex field and may be compared with other fields as engineering science, research and management of ecosystems and human health (Noll-Minor, 2017). These are fields, where transdisciplinarity is the prevalent research principle.

The transdisciplinary research process is organized in three phases that may be passed through several times: identification and structuring of problems, working at and solving (or at least mitigating) problems, valorization and transdisciplinary integration.

In conservation-restoration the first phase of identification and structuring of problems may be interpreted as an investigation of fabrics and condition, as a search for causes and as an identification of the needs of stakeholders. The object of Cultural Heritage may be regarded as a complex structure with internal factors (fabrics, materials) which are in interaction with the environment and which are influenced by aging and altering processes. The act of inspection of the given object records just a single snapshot in a changing system. The object is regarded through "filters" of description and analysis of fabrics, on the one hand, and phenomena of aging and alteration on the other. The investigation and interpretation of the findings lead from recording traces of design and alteration to the inference of the techniques of creation as well as of the dynamics of alteration processes, their causes and potential threats. The problem solving phase includes the discussion and evaluation of intermediate results, it may lead to a decision for the need for appropriate further investigations, which may include the visualization of processes of change (looking into the past and/or in the future) and development of conservation approaches.

The discussion of values in cultural heritage is an example of valorization and transdisciplinary integration as an outcome of the investigation of its fabric, its condition, and its immaterial meaning. This includes the integration of conservation approaches into broader strategies that negotiate maintenance and use. 
Another aspect or meaning of transdisciplinarity, namely "to develop knowledge and practice that promote what is perceived to be the common good" (Hirsch 2008) relates to a discourse on approaches and concepts in relation to Cultural Heritage within a broader professional and social context.

In the Faro Convention on values of cultural heritage (Faro 2005) a postulate has been expressed, which is particularly challenging for Conservator-restorers as it provokes a rethinking of prevalent and familiar theoretical and practical approaches in conservation sciences and ethics: It says that cultural heritage is renewable under certain circumstances and lead to a provoking definition of conservation as "management of change". Dean Sully (2007) describes it as follows: "Conservation is a process of understanding and managing change rather than merely an arresting process; it is a means of recreating material cultural heritage that seeks to retain, reveal and enhance what people value about the material past and sustain those values for future generations... objects are conserved because they are valued for the effect they have on people“. (Sully, 2007, p. 39)

Conservation specialists recognize material cultural heritage more than ever as a fragile and nonrenewable resource that enhances the quality of material, mental and spiritual life in our diverse cultures. It is a challenge and requires efforts to understand its complexity in each unique case, to communicate its value to society in order to enhance the interest to preserve it and finally to preserve its structure in all efforts to make it readable and useful for society (Noll-Minor 2014, p.76).

\section{Recent examples of transdisciplinary research and practice}

The following case studies exemplify the relevance of the transdisciplinary integration of research and practice in Conservation science and Conservation-restoration of Cultural Heritage.

\subsection{Case study A: Low-Tech-Monitoring of medieval wall paintings in Brandenburg (Germany)}

The systematic examination and documentation of medieval wall paintings and architectural surfaces is closely connected to developments in transdisciplinary research. Between 1987 and 1991, the German Federal Ministry for Research and Technology funded joint research projects entitled "Deterioration of mural paintings" (Segers-Glocke, 1994; Behrens et al., 2005) and "Deterioration of stone", which contributed substantially to the establishment of a scientific approach to the preservation of cultural heritage. Results of these projects included an attempt to normalize conservation measures through the formulation of standards (VDI, 1987; ICOMOS, 2003). The standards are currently being revised in reference to European and International standards.

Rising expectations for scientific investigations and documentation are often at odds with the financial means of the owner or responsible party, once research projects come to an end and give way to the daily reality of preserving historical monuments. This discrepancy has been receiving critical attention for quite some time. Therefore, the following criteria ensuring a methodological approach in the development of condition assessment and documentation have been proposed (Wong, 2000; Wong, 2003): In defining the level of detail and complexity of the condition assessment and associated documentation of the object, geographical and temporal conditions as well as the goal of the documentation should be carefully considered. This includes, prior to initiating the monitoring 
process, recording the extent and current condition of the wall painting with consideration of its physical and conservation-restoration history, as well as an investigation of deterioration processes and risk assessment. Furthermore, there is need for research in the field of development of "low-techmonitoring" procedures (Laue et al., 2008).

Current research within the federal state of Brandenburg regarding the investigation of extent, physical history, technique and condition of medieval plasters and wall paintings includes the results of two projects entitled "Environmental deterioration of historic plaster and mortar: research and conservation" (BLDAM, 1998) and "Environmentally induced pigment alteration of the gothic mural paintings in Ziesar castle and St. Mary's Church, Herzberg" (Fig.1, BLDAM, 2009), both funded by the Deutsche Bundesstiftung Umwelt (DBU, German Foundation for the Environment).

A recent project (also funded by the DBU) has been focusing on "Developing model conservation concepts by recording and monitoring medieval wall paintings in the northeast of Brandenburg that have sustained human-caused environmental damage" (BLDAM, 2018). It had two main branches of activity: 1 . Creating an inventory of medieval mural painting of this region; 2 . Developing a structured methodological approach in the development of condition assessment and its documentation.
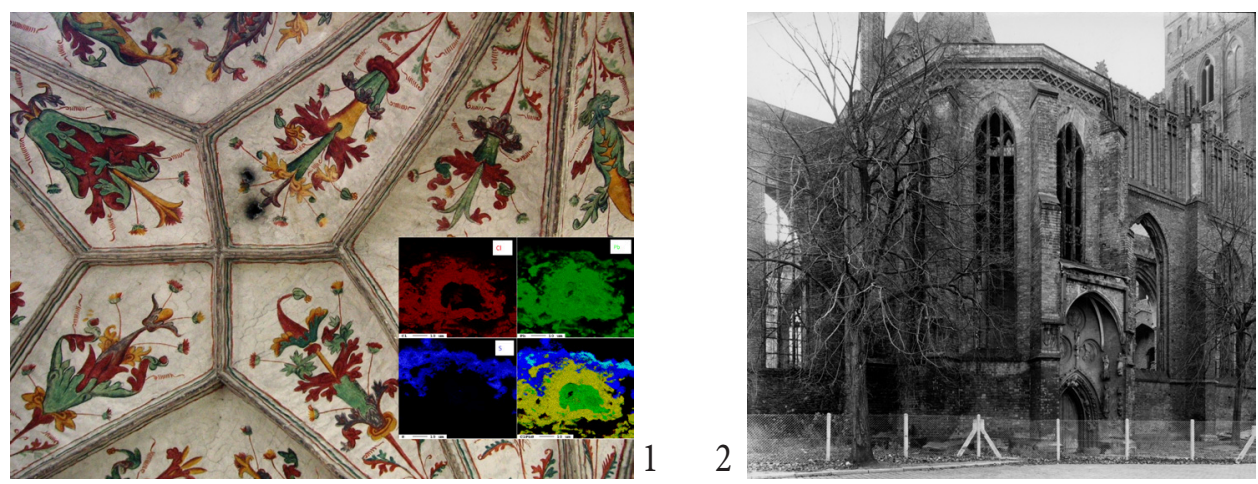

Fig. 1 Herzberg, St. Marys Church, Environmental induced pigment alteration - investigation by SEM/EDX, 2006; Photo: Jan Raue, Frank Schlütter

Fig. 2 Frankfurt (Oder), St. Mary's Church, view from North-east around 1950; Photo: BLDAM

Medieval wall paintings and architectural surfaces dating between the 13th and 18th centuries in about 50 churches have been recorded and published in the second volume of an inventory of medieval wall paintings in the federal state of Brandenburg (BLDAM, 2019). This region's highly significant cultural heritage boasts several famous examples of the Northern German Gothic brick style architecture. Within the project, twelve parish and monastic churches have been considered in more detail, among them, St. Mary's Church (Fig.2) in the former Hanseatic City of Frankfurt (Oder) with its unique medieval wall paintings decorating both its interior and exterior (Fig. 3-5). 

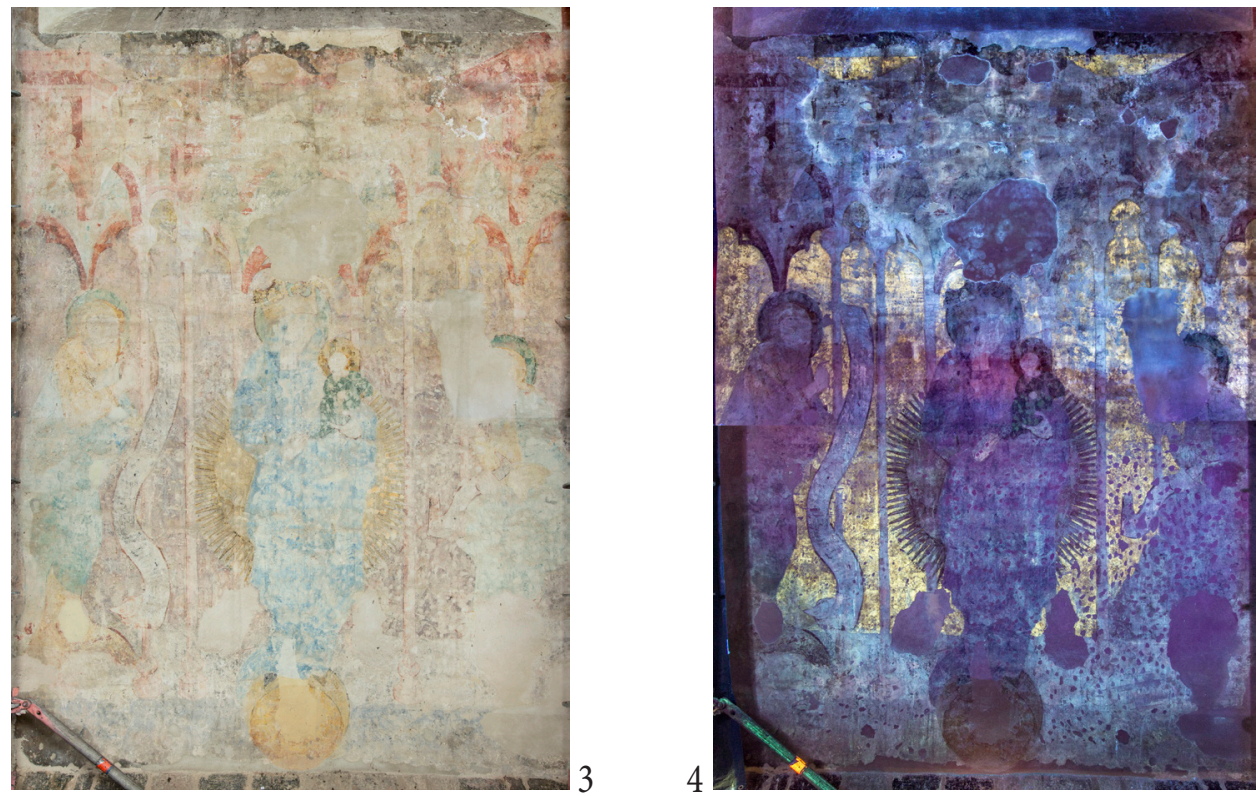

Fig. 3 Frankfurt, St. Mary's Church, Apocalyptic Virgin, photography taken under incident light; Photo: Holger Herschel

Fig. 4 Frankfurt, St. Mary's Church, Apocalyptic Virgin, photography taken under UV light; Photo: Holger Herschel



Fig. 5 Frankfurt, St. Mary's Church, Apocalyptic Virgin, reference photo, 2016; Photo: Mechthild Noll-Minor 
Both the current state of research and decades of in-situ experience confirm that avoidance of costs arising from large-scale conservation-restoration campaigns can be achieved through the development of a structured and continuous monitoring program specifically tailored to the site. The basis for such a monitoring program is created with the help of interdisciplinary surveys and consultation of exemplary research on medieval wall paintings and architectural surfaces. This includes the art historical investigation of the paintings, some of which are scarcely known, as well as examinations of historical church and monastery architecture in the field of building research. Seen from the vantage point of monitoring, these types of investigations are indispensable, as they enable the priorisation of interventive measures. When a significant object is at risk, a higher urgency is assigned to the intervention. This risk assessment also serves as a guideline for how parishes should invest their funds, and informs co-funding provided by church administration and subsidies from the federal state of Brandenburg.

A key component of the monitoring process is the scientific investigation of the extent and condition of wall paintings. These investigations can be implemented first using simple visual methods, such as the examination and photographic documentation of the objects using incident, raking and UV light). Research/analysis of archival materials also plays an important role. The known facts about the conservation-restoration history of the objects should be taken into account in the assessment of their actual preservation states.

The study of original (plaster and painting) techniques, the characterization of deterioration of the paint and plaster layers and the identification of the causes of these degradations are also essential steps of the interdisciplinary survey. These studies inform our conception of the original appearance and highlight ongoing deterioration processes.

Scientific investigations focus on the analysis of constituent materials and techniques, damaging salts and contaminants (pollutants), environmental monitoring (temperature and relative humidity), and lead to more complex questions regarding, for instance, pigments' alteration in wall paintings. Environmental factors, such as climate and salts, can cause drastic changes to the appearance of the often fragmentary painted surface, sometimes resulting in false conclusions regarding iconography. For example, as a result of such studies, the identification of the iron pigment, vivianite, originally blue in appearance, was made possible despite the fact that today it is most frequently observed in its altered state displaying a brownish-yellow appearance. This discovery provides insight into colour iconography: A significant example is the inner "space" of the mandorla in the depiction of Christ as the Pantocrator in the wall painting panel at St. Johannis church in the town of Brandenburg which was originally meant to appear blue as a view into heaven (Fig. 6). In depth studies are of importance in order to understand how environmental parameters can have an influence in the chemical degradation of the mineralogical constituents of the paint layers. 


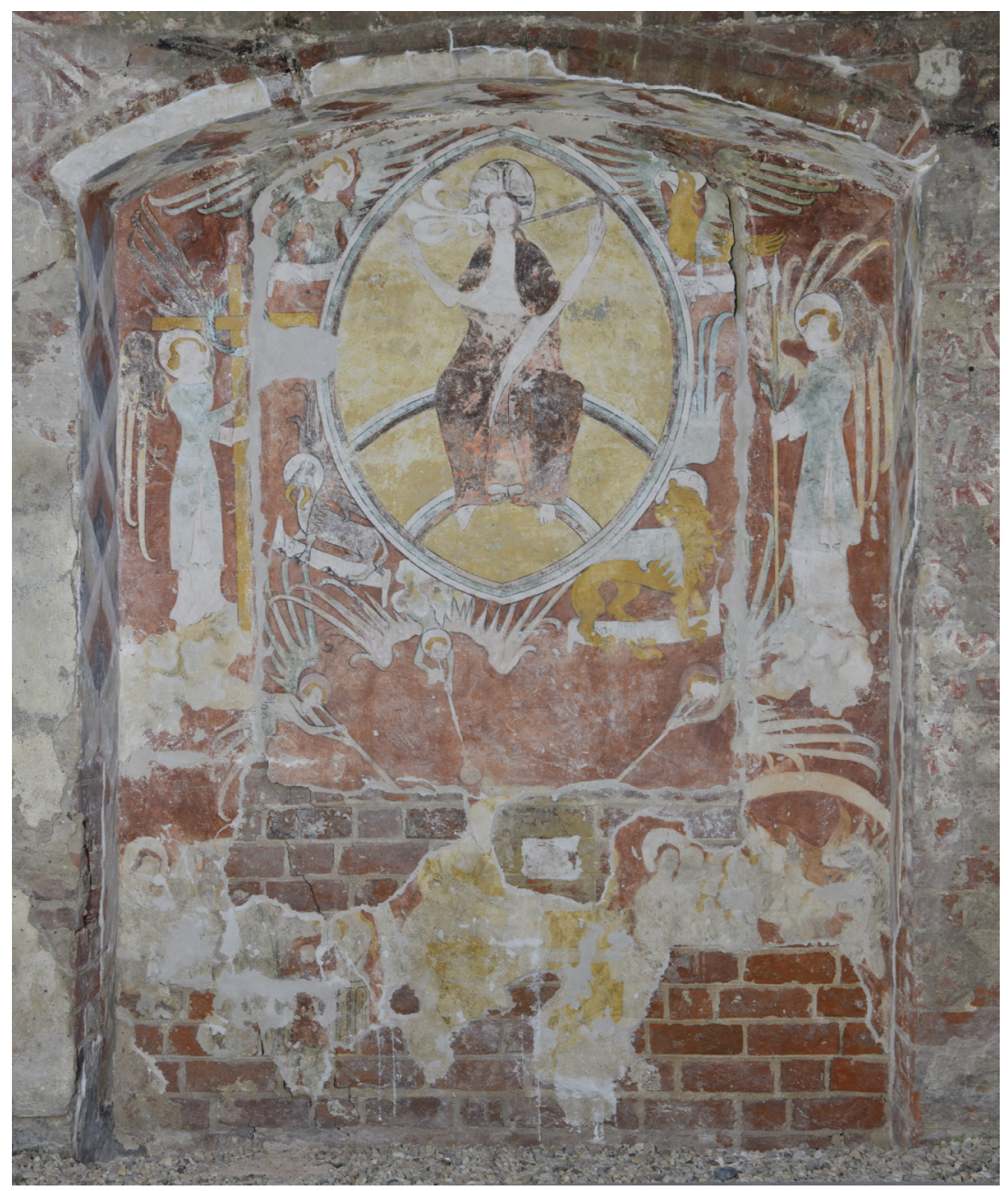

Fig. 6 Brandenburg, St. Johannis, Christ as the Pantocrator (judge of the world), 2016; Photo: Mechthild Noll-Minor

These studies are carried out in cooperation with the Potsdam University of Applied Sciences, the University of Potsdam and the Bremen Institute for Materials Testing (MPA) using complementary analytical techniques including X-ray Fluorescence (XRF), polarization microscopy, Scanning Electron Microscope coupled with Energy-dispersive X-ray spectroscopy (SEM/EDX) and Raman spectroscopy (Fig.7). Such background knowledge is a prerequisite for a more in-depth characterization of changes in paint and plaster layers, providing insights into possible mechanisms of deterioration and enabling the evaluation of risks to the wall paintings and architectural fabric as part of a monitoring program. These studies also helped to identify a range of reference areas selected for long-term monitoring, which can be used for repeated condition assessment over time. For selected objects, it was possible to carry out in-depth graphic documentation of extent and condition in connection with conservation measures, at times with the support of research undertaken by students. 


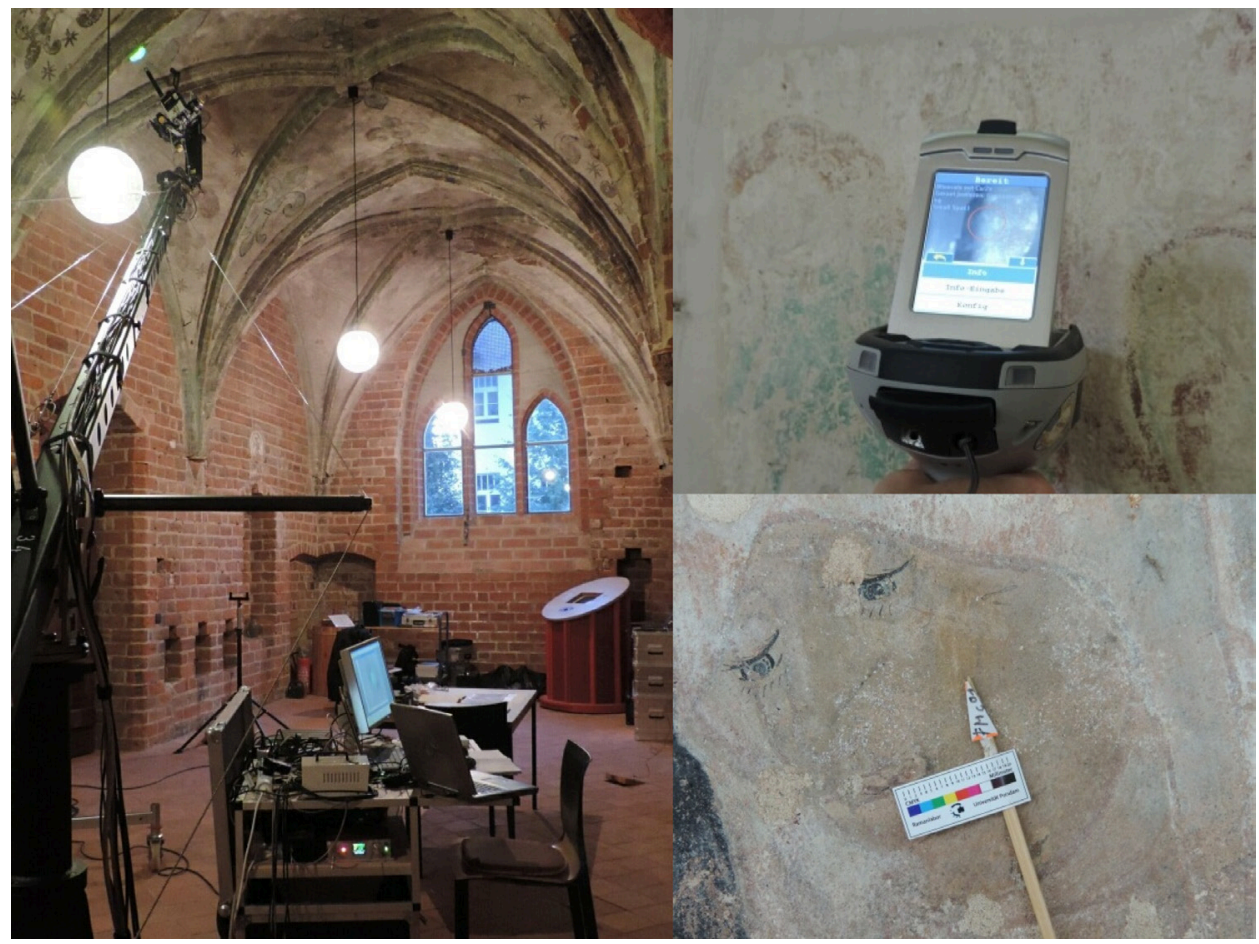

Fig. 7 Angermuende, sacristy; Chorin, monastery and Frankfurt (Oder), St. Mary's church, investigation by Raman spectroscopy and mobile XRF, 2016; Photo: Martin Ziemann

Using this relatively complex and somewhat time-consuming method to build a basis serves to ensure high quality monitoring, thereby facilitating resource-saving and sustainable cultural heritage conservation. Instead of striving for large-scale, far-reaching conservation interventions, the aim is to perform regular controls and implement small-scale conservation measures to minimize material, financial and professional costs and reduce the strain on cultural heritage as much as possible.

The low-tech monitoring procedure developed as part of a project (BLDAM, 2017) shall be used as a model for ,best practice' for future projects dealing with in-situ decorative schemes in churches and monuments.

\subsection{Case study B: Holy Sepulchre of the former monastery Neuzelle in Brandenburg (Germany)}

The village and former monastery Neuzelle is situated in the state of Brandenburg, south of Frankfurt (Oder) and close to the Polish border. The Holy Sepulchre of Neuzelle with its five stage sets and 15 figural scenes is a stage installation or "passion theatre" with an extraordinary rich theological and narrative content (Noll-Minor, 2005). Alongside the main stations of the "Way of the Cross," it comprises also scenes and citations from the Old and New Testament incorporating deictic realizations of theological concordances (Fig. 8 and 9). 

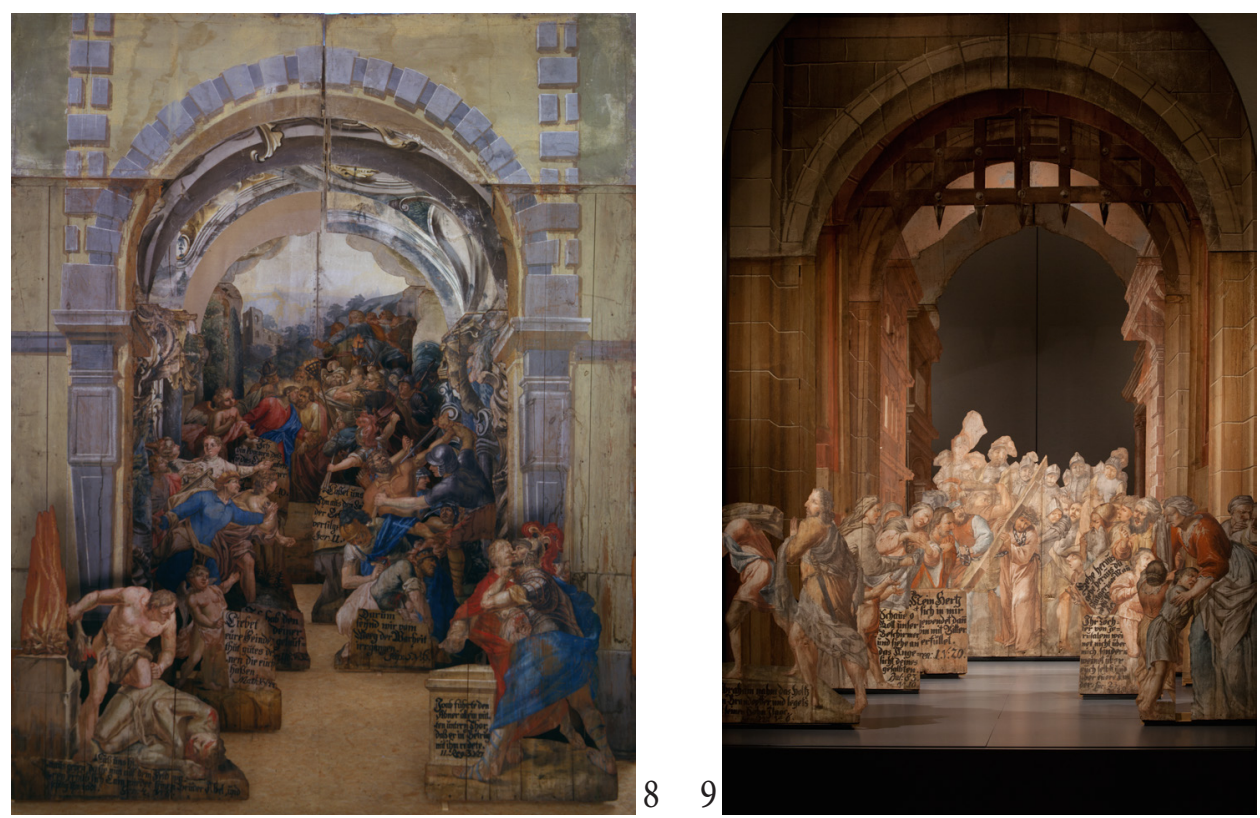

Fig. 8 Neuzelle, former monastery, Holy Sepulchre, scene Judas Kiss in stage set Garden, temporary installation in the Conservation studios of the BLDAM, 2004; Photo: Dieter Möller

Fig. 9 Neuzelle, former monastery, Holy Sepulchre, scene Bearing of the Cross in stage set Civitas, installation in the museum "Himmlisches Theater" at Neuzelle, 2004; Photo: Mechthild Noll-Minor

From a cultural point of view, it is interesting to mention the historical "cross-cultural" context of the passion theatre Holy Sepulchre at the time of its creation. In the middle of the 18th century the monastery of Neuzelle formed a Catholic enclave in a Protestant neighborhood. The creation and subsequent liturgical use of such a large-scale program of scenes and figures was obviously motivated by this specific circumstance. It is evident that the intention was to impress, to educate and to proselytize. Texts from the Old and New Testament have been incorporated in order to communicate and to explain the respective contents, both, to the Catholic and to the non-Catholic population. (Töpler, 2005)

The conservation project was closely connected with the investigation of different aspects of the historic background and liturgical use of the passion theatre. The knowledge of the immaterial aspects of the object together with the results of technical investigation of the original substance, shape, traces and condition report contributed to the conservation approach and concept for future presentation.

Together with the main installation of the Neuzelle Holy Sepulchre a paper model (built to a scale of one to ten) has been preserved, that dates back to 1751. It shows 4 of the 5 stage sets and almost all of the 15 figurative scenes. Both - the model and the theatre - have been created by Joseph Felix Seyfrit from Bohemia, "Pictor et Architectus", who signed on the reverse of the main figure in the scene Judas' Kiss (Fig.8). For the creation and production of the passion theatre he must have had assistants and co-operators in his studio (Venhorst, 2005 and 2015). 
Although the 261 single components of the passion theatre were in a desolate state when found and often broken into even more pieces, it was possible to identify almost all of them prior and during their technological investigation.

All traces and holes from nails, screws, pins and all marks left by frequent use, by assembling and by dismantling the giant object were investigated and precisely mapped. The IT-supported evaluation of these tracesled to various conclusions. Every backdrop shows nail holes of candleholders and sometimes traces of soot and wax on its reverse. The comparative evaluation of the traces demonstrates that every figure was illuminated by lights mounted on its preceding backdrop, according to its individual height and dimension. One of the scenes - the "palace" - represented "artificial light" through the use of glass globe (sphere), filled with colored water and illuminated by candles - thus shining through round holes in the backdrops.

The last presentation of the theatre in liturgical function dates from 1863. Damage, expenses for the annual installation, and finally an outdated style of the theatre led to the abandonment of this tradition. There are inscriptions with date specifications on the reverses of the backdrops, which indicate that in the last decades of use only one stage set with two or three scenes had been presented in conjunction with the (possibly more recent) resurrection scene according to a seven years rotation principle.

During the following 140 years all parts of the passion theatre suffered from moisture and decay because of inadequate handling during rearrangement etc. In the first half of the 20th century toxic pesticides on the basis of DDT (Dichlorodiphenyltrichloroethane) and Lindane (Gamma-Hexachlorocyclohexane) were applied against insect infestation. The high content of DDT at the surface and subsurface of all pieces of the theatre made the handling a potential risk for the conservator's health. The problem of decontamination was subject to a research project together with the Rathgen Research Laboratory in Berlin under the direction of Achim Unger in the years 2002-2003. This research was carried out within the framework of a joint project sponsored by the Deutsche Bundesstiftung Umwelt (DBU) as well as in immediate cooperation with the conservator-restorers. - The "state of the art" decontamination of wooden artefacts using a vacuum washing procedure has been integrated subsequently in a technical specification of the Wissenschaftlich-Technische Arbeitsgemeinschaft für Bauwerkserhaltung und Denkmalpflege (see following chapter).

\section{Framework for continuing quality assessment in Conservation science and Conservation- restoration}

At the turn of the millennium a European Rafael project "Actors in Cultural Heritage and the legislation" (APEL, 2001) under the direction of E.C.C.O. (European Confederation of Conservatorrestorers organizations) could be accomplished. The scope of the project was to review the existing legislation and the real interdisciplinary practice in Cultural Heritage. The obtained results gave a deeper insight into the common work and efforts of different players to "preserve" or "maintain" Cultural Heritage. The project led to the formulation of Guidelines for the framework of professional practice in Conservation-restoration. 


\title{
4.1 Conservation process and required competences for access to the profession of Conservator- restorer
}

The implementation of this procedure in conservation-restoration projects guarantees the quality of the interventions and the long-term preservation of cultural heritage if the following competence and quality requirements are followed and the allocation of specific budgets is provided. (APEL 2001):

Inception of conservation projects: The involvement of conservator-restorers in the development of strategic and managerial policy concerning cultural heritage should be explicitly anticipated and specified.

Preliminary examination, diagnosis and decision on intervention: This essential stage of a conservationrestoration project, including documentation, requires the allocation of a specific budget.

Project formulation and its approval, implementation planning: The responsibilities of each of all actors involved in this stage (owner, public authority, conservator-restorer, architect, engineer, etc.) must be identified. The role of the conservator-restorer as conservation specialist in the project formulation should be explicitly anticipated and specified.

An example of the correspondence between the planning activities of conservator-restorers and architects is given in the following scheme in accordance with the Fee Structure for Architects and Engineers (HOAI) (Fig.10).

The required competencies of conservator-restorers have been elaborated and explained through a concept scheme of the conservation process together with a taxonomy of knowledge (Corr et al., 2011).

\author{
Conservation-restoration specialist planning \\ in accordance with the Fee Structure for Architects and Engineers (HOAl): \\ phase 1. project inception, including basic evaluation and preliminary investigations \\ phase 2. preliminary planning with sizing estimate \\ preliminary examination, diagnosis and decision on intervention \\ phase 3. project planning with preliminary estimate \\ project formulation including advanced examinations and tests \\ phase 4. approval planning \\ formulation of "conservation-restoration plan"
}

phase 5. implementation planning with Commitment estimate

phase 6 . specifications for tender

implementation planning and specifications for tender

phase 7. participation in award of contract

phase 8 . building surveillance, construction management or site supervision

specialised site management

phase 9. object maintenance and documentation (including scientific management and monitoring) evaluation of intervention and documentation

Fig. 10 Scheme of correspondence of Conservation-restorer specialist planning with HOAI, Mechthild Noll-Minor, 2014; Photo: Mechthild Noll-Minor 


\subsection{Dissemination of research results, implementation into technical specifications and strategies of maintenance}

In the first instance, the results of research projects are communicated in scientific articles. But beyond that the research outcome needs to be made accessible for decision makers and to be linked to other activities in the sector of Cultural Heritage in order to close the gap between high level research projects and the development and assessment of proficient professional practice in Conservation science and Conservation-restoration.

Quality assessment of good professionalism through standards is attractive to politicians and decision makers. Research increases know-how in the field. Hence the transfer of knowledge from research results through state-of-the-art descriptions in guidelines and standards is a challenging process. Therefore, the experts involved in standardization have to carefully assess what kind of professional activity is suitable for standardization. A critical review of the existing and drafted standards is necessary to prevent the community from all too mechanistic procedures in the regulation of their work which do not reflect the state-of-the-art in conservation science and conservation.

"Best practice" in German speaking countries are the activities of the Wissenschaftlich-Technische Arbeitsgemeinschaft für Bauwerkserhaltung und Denkmalpflege (WTA - Scientific technical association for building maintenance and monument preservation). The association supports the dissemination of research results and its practical application in the field of building maintenance and monument preservation through publication of procedures and methods in technical specifications, thus enhancing the application of new findings and modern technology. To achieve these objectives, an intensive dialogue between researchers and practitioners has been established. WTA fulfills these tasks by hosting expert dialogues, seminars and conferences and by working out and publishing guidelines on current topics by specifically appointed working groups. During its 25 years of existence, the association WTA has produced a great number of technical specifications, and materials are being certified according to WTA-standards. The commercial value of these certifications is based on the scientific value of the WTA-specifications.

\subsection{Institutional funding of long term Conservation science projects and service for Cultural Heritage}

The history of Conservation science has proven that long term projects and close collaboration are essential to perform research in this field. During the "ICCROM Forum on Conservation Science", held in Rome 2013, the leading role of conservation institutions has been described to further develop and promote the relevance of Conservation science as a transdisciplinary field (Corbeil, 2015): „The first message is a general statement of the fact that conservation science is an essential part of conservation. The other messages provide guidance to conservation institutions so that they can achieve maximum impact. Conservation institutions should engage in research and development that anticipate issues, provide sustainable solutions and guidelines, and are conducted in a transdisciplinary way."

Conferences and colloquia organized by these institutions enable the sharing of expertise via research results and practical experiences.

The assessment and funding of conservation science projects should take into account - among other criteria - the amount of transdisciplinarity in the collaboration of the involved partners. 


\section{Bibliography}

Behrens, E., Berling, H., Hornschuh, A., Niemeyers, R., Recker, B., Schwarz, H-J. \& Stadlbaur, E. (2005): Wandmalerei-Referenzflächen-Monitoring am Beispiel der Stiftskirche Königslutter - Methoden und Erkenntnisse für die praktische Denkmalpflege. In: Berichte zur Denkmalpflege in Niedersachsen 1/2005 (pp. 9-12). Hameln: CW Niemeyer

BLDAM (1998): Erforschung und Erhaltung historischer Putze und Mörtel im Hinblick auf Umweltschäden. Arbeitshefte des Brandenburgisches Landesdenkmalamtes und Archäologischen Landesmuseums Nr. 9. Worms: Wernersche Verlagsgesellschaft

BLDAM (2009). Umweltbedingte Pigmentveränderungen an mittelalterlichen Wandmalereien. Arbeitshefte des Brandenburgisches Landesdenkmalamtes und Archäologischen Landesmuseums Nr. 24. Worms: Wernersche Verlagsgesellschaft

BLDAM (2010). Mittelalterliche Wandmalerei in Brandenburg, Band 1: Der Südosten - die Brandenburgische Lausitz. Forschungen und Beiträge des Brandenburgisches Landesdenkmalamtes und Archäologischen Landesmuseums. Worms: Wernersche Verlagsgesellschaft

BLDAM (2019). Mittelalterliche Wandmalerei in Brandenburg. Band 2: Der Nordosten - Orderland, Barnim und Lebus. Forschungen und Beiträge des Brandenburgisches Landesdenkmalamtes und Archäologischen Landesmuseums. Worms: Wernersche Verlagsgesellschaft

Corbeil, M.C. (2015). Conservation institutions as agents of change. In: Studies in Conservation 2015 VOL. 60 SUPPLEMENT 2 "Conservation science", pp. 2-32

Corr, S., Hutchings, J., van der Burg, J., Cueco, D. A., Noll-Minor, M., Ortlik, A. G., \& Dobrusskin, S. (2011). Competences for Access to the Conservation-Restoration Profession. Brussels: E.C.C.O.

Council of Europe (Ed.). (2006). Council of Europe Framework Convention on the Value of Cultural Heritage for Society: Faro, 27. 10. 2005 = Convention-cadre du Conseil de l'Europe sur la valeur du patrimoine culturel pour la société. Strasbourg: Council of Europe Publications

E.C.C.O. (2001). Acteurs du Patrimoine Européen et Législation. Survey of the legal and professional responsibilities of the conservator-restorer in regard of the other parties involved in the preservation and conservation of cultural heritage. Rome: E.C.C.O

ICOMOS (2003): Principles for the Preservation and Conservation-Restoration of Wall Paintings, In: Petzet, M. (Ed.). International Principles of Preservation. ICOMOS Monuments and Sites XX, pp. 88-91. Berlin: Hendrik Bäßler Verlag

IOM - International Institute of Museums (1940). Manual on the conservation of paintings. International Institute of Intellectual Cooperation, URL: https://atom.archives.unesco.org/manuelde-la-conservation-des-peintures

Hirsch Hadorn G., Hoffmann-Riem H., Biber-Klemm S., Grossenbacher-Mansuy W., Joye D., Pohl C., Wiesmann U. \& Zemp E. (Eds.). (2008). Handbook of Transdisciplinary Research. Springer Netherlands Laue, S., Bläuer, C. \& Stadlbauer, E. (2008). Stand des Wissens und Forschungsdefizite. In: Salzschäden an Kulturgütern (pp. 59-65). Osnabrück: Deutsche Bundesstiftung Umwelt

Mittelstrass, J. (2003). Transdisziplinarität - wissenschaftliche Zukunft und institutionelle Wirklichkeit. Konstanz: UVK Universitäts-Verlag Konstanz 
Nadolny, J. (2012), A history of early scientific examination and analysis of painting materials ca. 1780 to the mid-twentieth century, In: Stoner, J.H. \& Rushfield, R. (Eds.). Conservation of Easel Paintings, (pp. 336-340). London: Taylor \& Francis

Noll-Minor, M. (2005). The scene "Juda's kiss" in the stage set Garden of the Passion theatre Holy Sepulchre of Neuzelle; In: Brandenburgisches Landesamt für Denkmalpflege und Archäologisches Landesmuseum (Ed.). Das Heilige Grab Neuzelle - Untersuchung und Konservierung der Szene „Judaskuss" im Bühnenbild „Garten”, (pp. 109-111). Petersberg: Michael Imhof Verlag

Noll-Minor, M. (2014). Conservator-restorers and other actors in building conservation transdiciplinarity as a challenge, In: Grup tecnic (Ed.). La conservació arquitectònica, un treball en equip, (pp. 71-85). Barcelona: Conservadors-Restauradors Associats de Catalunya

Noll-Minor, M. (2017). Erforschen und Erhalten - transdisziplinäres Arbeiten in der Denkmalpflege. In: Verband der Restauratoren (Ed.). FORWARD- Forum wissenschaftliches Arbeiten in Restaurierung und Denkmalpflege. Eine Bestandsaufnahme zum Europäischen Kulturerbejahr 2018, (pp. 33-39). Bonn: Verband der Restauratoren

Rathgen, F. and Borrmann, R. (1916). Über Versuche mit Steinerhaltungsmitteln (IV. Mitteilung). In: Zeitschrift für Bauwesen 66, Heft 7/9, pp. 349-358

Segers-Glocke, C. (1994). Forschungsprojekt Wandmalerei-Schäden: ein Förderprojekt des Bundesministers für Forschung und Technologie. Schlußbericht zu den interdisziplinären Befunden. Arbeitshefte zur Denkmalpflege in Niedersachsen,11. Hameln: C W Niemeyer

Stoner, J.H. (2015). Vignettes of interdisciplinary technical art history investigation. In: CeROArt [Online], HS, Online since 10 April 2015, connection on 30 December 2018. URL: http://journals. openedition.org/ceroart/4508

Stout, G.L. (1949). Long-range conservation. In: The Museum News, Vol. 27 Nr.5, p. 7-8

Stout, G.L. (1950). The viewpoint of the conservator. In: Cercle des Alumni des Fondations Universitaires. Art et science. Alumni, 19, pp. 282-291

Sully, D. (2007). Colonising and Conservation. In: Sully, D. (Ed.). Decolonising Conservation: Caring for Maori meetinghouses outside New Zealand (pp. 27-43). Walnut Creek, CA, Left Coast Press

Töpler, W. (2005). Das Kloster Neuzelle und sein Heiliges Grab. In: Brandenburgisches Landesamt für Denkmalpflege und Archäologisches Landesmuseum (Ed.). Das Heilige Grab Neuzelle - Untersuchung und Konservierung der Szene „Judaskuss” im Bühnenbild „Garten”, (pp. 13-17). Petersberg: Michael Imhof Verlag

VDI (1987). VDI 3798 -Untersuchung und Behandlung von immissionsgeschädigten Werkstoffen, insbesondere bei kulturhistorischen Objekten. Verein Deutscher Ingenieure VDI. Düsseldorf: VDI Verlag GmbH

Venhorst, E.E. (2005). Kunsthistorische Betrachtungen zum Heiligen Grab aus der Stiftskirche St. Marien zu Neuzelle. In: Brandenburgisches Landesamt für Denkmalpflege und Archäologisches Landesmuseum (Ed.). Das Heilige Grab Neuzelle - Untersuchung und Konservierung der Szene „udaskuss” im Bühnenbild „Garten” (pp. 18-27). Petersberg: Michael Imhof Verlag 
Wong, L. (2000). Questionnaire Summary: Condition Recording in the Field of Wall Painting Conservation. In: GraDoc - Graphic Documentation Systems in Mural Painting Conservation (pp. 315330). Rome: ICCROM

Wong, L. (2003). Documentation: Objectives, Levels and the Recording Process. In: Gowing, R. and Heritage, A. (Eds.). Conserving the Painted Past: Developing Approaches to Wall Painting Conservation, (pp. 46-54). London: James \& James 